\title{
Erratum to: Against Spiritual Ecology: Reply to Sponsel's Comments
}

\author{
Andrew P. Vayda
}

Published online: 7 December 2014

(C) Springer Science+Business Media New York 2014

\section{Erratum to: Hum Ecol (2014) 42:803-805 DOI 10.1007/s10745-014-9700-6}

In the second paragraph of the first page, the sentence that states: "Likewise, there is no inaccuracy in my stating that some of the chapters in Sponsel's book (2012), ike the one on the Burning Man festivals of the Nevada desert (chap. 17), have no clear relevance to an exposition of spiritual ecology or to the outline of its "intellectual history" which Sponsel (2012: xix) claims to be giving. " contains a mistake. The word "ike" should be corrected to "like". The sentence should read: "Likewise, there is no inaccuracy in my stating that some of the chapters in Sponsel's book (2012), like the one on the Burning Man festivals of the Nevada desert (chap. 17), have no clear relevance to an exposition of spiritual ecology or to the outline of its "intellectual history" which Sponsel (2012: xix) claims to be giving. "
The sentence that begins: "Thus, contrary to the premise, an article by Drew (2012) shows...points being made by 1998 and Alley 2000, cited by Drew,..." in the second paragraph of the first page, the author name in the citation 1998 is missing. It shoud read: "Thus, contrary to the premise, an article by Drew (2012) shows... points being made by Nagaranjan 1998 and Alley 2000, cited by Drew,..."

Also, the name Nagaranjan, V. R. was incorrectly written as Nagaraan, V. R. in the reference list. The correct reference is provided here:

\section{Reference}

Nagaranjan, V. R. (1998). The earth as Goddess Bhu Devi: Towards a theory of embedded ecologies in folk Hinduism. In Nelson, L. E. (ed.), Purifying the Earthly Body of God: Religion and Ecology in Hindu India. State University of New York Press, Albany, pp. 269-296.

\footnotetext{
A. P. Vayda $(\bowtie)$

Distinguished Professor Emeritus, Rutgers,

The State University of New Jersey,

New Brunswick, NJ, USA

e-mail: apvayda@gmail.com
} 